$\mathrm{SAD} / \mathrm{JSR}$

Sosyoloji Araştırmaları Dergisi / Journal of Sociological Research

Cilt / Volume 23 Sayı / Number 2 (Ekim / October 2020) : (1-33)
Araştırma Makelesi / Research Article

Geliş Tarihi / Submited: 06.01.2020

Kabul Tarihi / Accepted: 12.09.2020

\title{
HOW GOING TO COURT AFFECTS THE ATTITUDES TOWARDS COURTS
}

\section{Galma AKDENIZ ${ }^{1}$}

Seda KALEM ${ }^{2}$

\begin{abstract}
The aim of this paper was to explore how different types of experiences with courts shape attitudes towards the courts and the justice system, through a secondary analysis of data collected in 2006-2007 using a nationally representative sample of adult urban population of Turkey. Findings indicate that the attitudes of citizens with prior court experience are less positive than attitudes of those with no such experience. It is argued that a negative attitude towards the courts is the outcome of having an experience with the courts, rather than the other way around. It was found that satisfaction with the court experience positively influenced the attitudes towards courts for those who experienced court as civil and criminal plaintiffs, as well as observers and witnesses, while satisfaction with outcomes had same effect for criminal defendants. It is argued that attitudes towards courts are shaped by two components: The stable base which reflects a general and abstract trust in institutions, and a flexible component which is shaped by the nature of the experience and interaction that one has with the courts.
\end{abstract}

Keywords: Courts, Attitudes Towards Courts, Public Opinion, Judicial System, Justice 


\section{MAHKEME DENEYIMININ MAHKEMELERE YÖNELIK TUTUMLARINA} ETKÍSI

\section{ÖZ}

Bu makalenin temel amacı, farklı deneyimlerin mahkemelere ve adalet sistemine yönelik tutumları nasıl şekillendirdiğini araştırmaktır. Çalışma, 2006-2007 yılları arasında Türkiye genelinde yetişkin nüfus arasında gerçekleştirilen bir anket çalışmasının verilerinin ikincil analizine dayanmaktadır. Sonuçlar, mahkeme deneyimi olan kişilerin tutumlarının, hiç mahkeme deneyimi olmayan kişilere göre daha olumsuz olduğunu göstermiştir. Ceza davalarında mağdur ve hukuk davalarında davacı olanların yanı sıra izleyiciler ve tanıklar için de deneyimden memnuniyetin mahkemelere yönelik tutumu olumlu yönde değiştirdiği görülürken, sanıklar için memnuniyeti etkileyen esas unsurun deneyimden ziyade sonuç olduğu tespit edilmiştir. Aynı zamanda hükümete güvenin de tüm gruplar için mahkemelere yönelik tutumları belirleyici bir etkisi olduğu görülmüştür. Sonuç olarak, mahkemelere yönelik tutumların iki unsur üzerinden belirlendiği öne sürülür: katı olan bir temel bileşen, ve esnek ve deneyime dayalı bir bileşen. Katı temel bileşen, hükümete ve kurumlara yönelik daha genel ve soyut bir tutumun ve güvenin bir yansıması olarak görülürken, esnek bileşenin ise deneyimin özellikleriyle ve de kişilerin gerçekte mahkemelerde karşılaştıkları üzerinden şekillendiği öne sürülür.

Anahtar Kelimeler: Mahkemeler, mahkemelere yönelik tutumlar, kamuoyu, adalet sistemi, adalet 


\section{INTRODUCTION}

Few, if any, go to court voluntarily, and when they do, it is mostly due to problems or conflicts that could not be resolved in other ways. Consequently, even the idea of going to court for rather mundane matters "awakes unpleasant feeling" for many (Fix-Fierro, 2003, p. 5), let aside criminal cases which are usually "the most stressful interactions between citizen and government" (Casper, 1978, p. 237). Additionally, lack of prior experience with and knowledge about the judicial system, hence not knowing what to do, what to expect or how the process will work, can also increase parties' concerns about the fairness of the judicial process, leading to aggravated stress (Grootelaar, 2018). Overall, "a day in court", regardless of what the dispute is, or why the person is there in the first place, is likely to be an emotional and intimidating experience (Casper, 1978; Benesh \& Howell, 2001).

On the other hand, following the Weberian notion of legal rational authority, the legal system is also the foundation of the modern state's legitimate rule and as such holds the monopoly of the formal distribution of justice. Hence, despite unpleasant feelings, and in some cases even in the face of increasing dissatisfaction with and lack of confidence towards the judicial branch, people still resort to courts. Legal anthropology has provided us with multiple reasons as to why people invoke court's authority, varying from a sense of entitlement (Merry, 1990) to a belief in the law as a powerful resource (Turk, 1976), to more practical ones like when alternatives have been consumed and litigation is the last resort or where parties see courts as rather strategic weapons (Jacquot \& Vitale, 2014). Understanding these motivations for going to court is crucial for placing the formal justice system among the larger set of dispute resolution mechanisms available to people. Such an inquiry into these motivations also needs to be accompanied with a parallel questioning of the reasons keeping people away from courts (Silbey, 2005, p. 326). Both questions, why and why not, ultimately allow for an understanding of the existing legal culture, particularly when these individual decisions "reflect the wider array of social forces more than the facts of specific incidents" (Silbey, 2005, p. 325).

Aside from these reasons shaping people's decisions for invoking court's authority, legal culture is also constituted by what happens when people actually go to the courts. Granted, ideas about the law and the 
legal system in a given society are mostly determined by people's experiences with some face of the law, whether it is through a traffic offense, a work application or through any kind of contract we get into (Macaulay, 1987; Silbey \& Cavicchi, 2005). Silbey even argues that the law is durable and powerful because "a good part of legality is just this invisible constraint, suffusing and saturating our everyday life" (2005, p. 331). Among these experiences, however, people's direct or indirect engagement with the courts seems to have a particular effect on how the public views and understands the law and the legal system. The question whether or to what extent the trial is the "icon of the rule of law" (Silbey, 2005, p. 331) remains to be an empirical one, the answer to which is historically determined and bound to change. Nonetheless, courts as sites of justice -or injustice for that matter- continue to play a definitive role in the ways in which people imagine and relate to law in a given legal culture. At the same time, the decision to take a dispute to court involves abandoning of the direction of the conflict which requires "accepting entry into the juridical field" (Bourdieu, 1987). This invitation of law into people's lives can also be interpreted as a sign of legitimacy of law in the eyes of people (Ewick \& Silbey, 1998), especially when it is understood as a certain consent to the existing authority (Weber, 1958).

In this sense, maintenance of this legitimacy in the eyes of the people comes up as a public policy issue which requires governments and judicial apparatus to develop measures to ensure that courts remain to be relevant mechanisms for the people (Bühlmann \& Kunz, 2011). Therefore, in this paper, we intend to explore the impact of experience on citizens' attitudes towards courts in Turkey, using a secondary analysis of data collected in 2005-2007. The aim of this analysis is to study if and to what extent citizens' first-hand experience with courts and their satisfaction with that experience influence their attitudes towards courts and the justice system. The data is more than a decade old, but since the main objective of the paper is to study the impact of having an experience with the court on the ways in which people feel and think about the courts, we propose that the nature of this relationship does not change from year to year. That is to say, the focus is not on whether or not public in Turkey is satisfied with their experience of courts or what factors in fact shape their experiences as these are always open to change. Rather, we question whether first-hand engagement with courts and the satisfaction with this experience 
has any effect on the ways in which people evaluate the judicial system. In this regard, we argue that the findings regarding this relationship would hold today as well.

\section{RELEVANCE OF EXPERIENCE ON ATTITUDES: SIGNIFICANCE OF ROLES AND ASSOCIATED EXPERIENCES}

An attitude is commonly defined in social psychology literature as a way of thinking and feeling about something, or as cognitive representation of evaluations, which "serve(s) a fundamental role in relating an individual to the social world" (Olson \& Zanna, 1993, p. 120). ${ }^{3}$ In other words, attitudes organize what we know and how we feel about objects, events, structures, in the world, and predispose us to behavior. This is called a tripartite model of attitudes, as it proposes that attitudes consist of affective, cognitive, and behavioral components (Rosenberg \& Hovland, 1960; Breckler, 1984), meaning that they embody how we feel, what we believe, and how we think we would act in relation to a subject of the attitude.

While behavioral component is crucial to the structure of the attitude, attitudes themselves do not always or necessarily result in a particular behavior. In fact, research shows that attitudes and behaviors can differ significantly because people do not always act in accordance with the way they feel or think because attitudes are in fact more context bound than was assumed (Bohner \& Schwarz, 2001). As evaluative processes, attitudes can develop and change through processes of socialization, as we observe and internalize certain ways of thinking and feeling. Experiences, direct or indirect, personal or vicarious, are the primary determinants in these processes of attitude formation since they allow subjects to develop certain evaluations about any particular matter, no matter how specific. ${ }^{4}$

\footnotetext{
${ }^{3}$ For a brief overview on the different ways in which social psychology literature has approached the concept, see Schwarz \& Bohner, 2001, and Olson \& Zanna, 1993.

${ }^{4}$ Examples of such specific relationship between experience and attitudes include the impact of experience with disabled people on children's attitudes towards this group (Hazzard, 1983), older people's experience with computers and their attitudes towards computers (Jay \& Willis, 1992), or the harassment experiences and its impact on attitudes towards harassment and sex roles (Mazer \& Percival, 1989).
} 
When it comes to the impact of experience with courts on attitudes towards courts and the justice system, so far research findings have been mixed: while some show that experience improves attitudes towards courts (Kritzer \& Voelker, 1998; McCoy \& Jahic, 2006), there is also an abundance of research arguing that experience leads to more negative evaluations (Rottmann, Hansen, Mott, \& Grimes, 2003; Wilson, 2012; Pleasence \& Balmer, 2018). Experience, however, is a complex and dynamic category. An experience with courts is shaped to varying degrees, depending on context and time, by numerous factors such as expectations from the justice system, knowledge about law and courts, the outcome and the process, as well as the role that one plays in the judicial process, all of which could further be influenced by class, gender, age, education and other demographics as well as by larger political and social forces etc. ${ }^{5}$ In the following pages, we briefly look into the impact of these factors upon court experiences, with a particular focus on how one's roles in the system can shape his/her experience with the courts, and arguably his/her attitudes towards courts.

\subsection{Expectations and Knowledge}

Luhmann (2004) argues that what in fact differentiates law from other social systems is its function to maintain -or stabilize- expectations in the face of disappointment. In this formulation, an expectation is taken as a communication about what is approved and what will be approved, rather than as a psychological issue. Accordingly, the greatest advantage of law compared to other systems is its capacity to maintain the normative expectation that it will deliver what it promises. Hence, it is when people no longer expect and believe that thieves will in fact be captured and punished -regardless of whether in reality they actually do get captured and punished- that law fails to deliver what it promises (Luhmann, 2004).

Empirically, however, expectations are not formed purely at the normative level. In fact, quite often, they are shaped through our knowledge -whether accurate or not- of the legal system. When O'Barr and

${ }^{5}$ For an extensive review of the factors that determine the relation between the public and the justice system, please see (Wilson, 2012).

SAD / JSR

Cilt / Volume 23 Sayı / Number 2 
Conley looked into the ethnographic reality of judicial process for everyday litigants in the civil justice system, they found out that litigants failed to realize the fundamental distinction between civil and criminal procedure; and this misunderstanding resulted with dissatisfaction with the small-claims process (1988). Having limited knowledge of the adversarial nature of civil litigation, litigants in fact believed that it would be similar to the criminal justice process where they, as complainants, would carry no burden of investigation (O'Barr \& Conley, 1988). ${ }^{6}$ Hence, the provision of even basic information about the system is proven to improve the perceptions and attitudes of the users (Chapman, MirrleesBlack, \& Brawn, 2002; Quinton, 2011). Scholars have also looked into the impact of vicarious experiences with the legal system upon attitudes towards judicial authorities (Brunson, 2007; Mondak, Hurwitz, Peffley, \& Testa, 2017). The role of media in delivering information about the justice system (Kalem, Jahic, \& Elveriş, 2008; Wilson, 2012) and the accuracy of that information (Tunç, 2009) have been particularly favorable subjects of study in this field.

\subsection{Outcome and Process}

It appears only reasonable to assume that people would see courts that decide in their favor more favorably than those that rule against them, and that, therefore, "winning" or "loosing" in the court would be an important predictor of attitudes towards courts. There is indeed a plenty of research exploring the relation between case outcomes and satisfaction with the court experience. ${ }^{7}$ Nonetheless, this relation has also been complicated by other factors, above all by the impact of procedural fairness upon satisfaction with the experience. Casper, Tyler and Fisher (1988), for instance, have argued that among criminal defendants there was no direct effect of sentence severity on outcome satisfaction. In other words, getting a longer or harsher sentence alone did not automatically lead to negative evaluations of the court. More recently, Grootelaar and Van Den Bos (2018) have found that case outcome explained

\footnotetext{
${ }^{6}$ For instance, there is a considerable amount of research on how perceptions about the leniency of the criminal justice system is in fact the result of a lack of awareness about the actual decisions delivered by courts (Hough, Jackson, Bradford, Myhill, \& Quinton, 2013).

${ }^{7}$ For a review of such literature, please see (Moorhead, Sefton, \& Scanlan, 2007).
} 
less than $6 \%$ of variance in trust in judges, compared to almost $40 \%$ of variance explained by procedural justice related measures. In other words, seeing the process as fair had much greater positive effect on trust in judges, than getting desired outcomes from those same judges. It was further found that outcome became important only when courts were evaluated as poor from a procedural justice perspective. When courts performed well procedurally, outcome had very little impact on attitudes towards judges. Hence, the process itself can be a significant determinant of the court experience, which in turn shapes attitudes towards the justice system at large. When people evaluate their court experiences as fair, they are also more likely to think of courts -and the authority behind them- as fair as well (Grootelar, 2018).

A body of research that explored the relationship between the experience of the legal process and the attitudes of the court participants towards courts (Casper, 1978; Lind \& Tyler, 1988; Tyler, 1990; Benesh \& Howell, 2001; Benesh, 2006; Thibaut \& Walker, 1975) support the argument that attitudes and opinions regarding courts are associated with a number of socially and legally desirable outcomes. These include higher rate of acceptance of court decisions (Lind, Kulik, Ambrose, \& de Vera Park, 1993), increased belief in legitimacy (Hough, Jackson, Bradford, Myhill, \& Quinton, 2010; Hulst, Van den Bos, Akkermans, \& Lind, 2017; Tyler \& Huo, 2002), as well as obedience to laws (Tyler, 2006). In other words, viewing the process as fair has been found to be associated with positive attitudes towards courts in general, with more favorable views of court's decisions, and with higher compliance with those decisions as well.

\subsection{Roles Before Courts}

Last but not least, roles in the judicial process also shape experience with and attitudes towards the legal system. Thibaut and Walker's (1975) model predicts that perceptions of fairness will depend upon the distribution of control among disputants and decision makers in the courts. Research findings indicate that "roles" that allow the party to have more control over the justice process and put little at stake (such as being a member of a jury) are associated with more positive evaluations, and consequently attitudes, than roles that give the person less control over the process but put a lot at stake (such as being a defendant) (Benesh 2006; Benesh \& Howell, 2001). Roles, however, are not just about how we are 
positioned within the judicial process. Experience through roles is also complicated vis-a-vis factors such as race, ethnicity, and/or gender (Gibson, 2018; Higgins \& Jordan, 2005; Rottmann et.al., 2003; Sun \& Wu, 2006; Tyler, 2001).

Main research question of this secondary analysis of data is how experience with the courts shapes attitudes towards the courts. We are asking both whether having direct experience with courts can on its own predict how positive or negative one's attitudes towards the courts will be, and also whether the particular type of experience (meaning appearing before the court as a plaintiff, defendant, witness, and alike) shapes attitudes in a different way. Further, using available variables we will attempt to identify how satisfaction with one's experience with the court and with the outcome of the judicial process contribute to one's attitudes towards the courts.

\section{METHODOLOGY}

Data analyzed in this paper was collected in 2006-2007, as a part of a larger project that aimed to study the public's opinions, experiences, and expectations regarding the judiciary and courts. Results of that study have been published (Kalem, 2009). We have used the original database along with the metadata in this secondary analysis. Here we are providing only a brief summary of the methods used in the original study. Detailed description of methodology used in the original data collection (including sampling strategy and the survey tools) can be found in the original publication (Jahic \& Kalem, 2009, p. 39-42).

\subsection{Sample}

Target sample of 3000 participants was selected from voter-age urban population in Turkey. The sample was selected from biggest cities from each of the 12 NUT1 regions, with the number of the participants selected from each NUT region proportionate to the total population of the region. In 2007, total urban population of these 12 cities amounts to $46 \%$ of total population of Turkey (TÜiK, n.d.). Table 1 shows the structure of the sample by region/city. 
Table 1. Breakdown on the Sample Across Twelve Cities

\begin{tabular}{llll}
\hline NUT1 Region & Selected province & Number of Participants & \% of total \\
sample
\end{tabular}

In the next step, neighborhoods from which the household were drawn were randomly selected. Since population of individual neighborhoods varies between 100 to 100,000 , in order to maintain equal chances of selection for each household, selection likelihood for each neighborhood was multiplied by its population size.

In the next step, the real estate tax database was used to generate the list of streets for each selected neighborhood. Two streets were then randomly selected from each neighborhood. Within each street, every third household was approached for face-to-face interview.

Response rate was $60 \%$ (of all residential dwellings selected into the sample, "door opened" or not). In order to check the accuracy of data, $5 \%$ of interviews were audited by field supervisor, $35 \%$ were checked using follow-up phone call to the participant, and all were tested for internal logic. As a result of these controls, 72 interviews were excluded and repeated with substitute households, selected from 
the same street where the original interview was conducted. Additional households were included into the sample, as substitutes to internally inconsistent interviews. Final sample size was 3033.

Average age of the participants was 36.92 (SD =14.18). $30.3 \%$ of participants were single, $64.5 \%$ married, and $4.7 \%$ divorced or widowed. Education and income levels of participants can be seen in Tables 3 and 4 of the original publication (Jahic \& Kalem, 2009, p. 42).

\subsection{Questionnaire}

Questionnaire that was used in the original study covered a range of topics, including experience with the courts, attitudes towards courts, trust in institutions, interest in legal issues, familiarity with the legal system, and sources of information about the courts. In this analysis, however, only items regarding the experiences with the court, satisfaction with that experience and trust in institutions were used.

\subsubsection{Dependent Variable - Attitudes Towards Courts}

In order to develop an index measure of the attitudes towards the courts, participants were asked to evaluate statements shown in the Table 2 on a 5-point Likert scale.

Table 2. Items Used to Measure Attitudes Towards court

\begin{tabular}{ll}
\hline $\mathbf{1}$ & Courts conduct hearings at times that are suitable for working citizens. \\
$\mathbf{2}$ & Citizens are treated with respect in courts. \\
$\mathbf{3}$ & Hiring a lawyer is expensive. \\
$\mathbf{4}$ & Courts listen to testimonies attentively and give individuals an opportunity to express \\
$\mathbf{5}$ & I am afraid that I may not understand what was going on, if I was in court for any \\
$\mathbf{6}$ & Courts protect everyone equally. \\
$\mathbf{7}$ & Courts conduct trials in fast enough manner. \\
$\mathbf{8}$ & Court decisions are just. \\
$\mathbf{9}$ & Thanks to courts, society is safer.
\end{tabular}


10 Courts can protect individuals' rights.

11 Everyone going to court will get just treatment.

12 Courts are doing their job well.

13 Courts would protect my rights, even if I did not have a lawyer.

14 I would avoid taking my disagreements to courts.

Courts are impartial; man, woman, defendant, victim, plaintiff, everyone gets

15 impartial treatment.

Mean was calculated, with higher values indicates more positive attitudes regarding the courts. Reliability for this 15 item scale was found to be strong (Cronbach's $\alpha=0.86$ ). Items 3,5 , and 14 were found to reduce the reliability of the scale. Factor analysis also indicated that, while all the other items loaded on the same factor, explaining total of $39.42 \%$ variance, these three items emerged as unique factors on their own. They also did not correlate as well with the other items. When taken out of the scale, scale's internal reliability was increased (Cronbach's $\alpha=0.92)$. Court Attitude Index (CAI), that was calculated after excluding these three items, was used in further analysis.

\subsubsection{Independent Variables}

Three types of independent variables were used in this analysis: 1) Experience with the courts, 2) satisfaction with the experience with the courts, and 3) trust in institutions. In addition to these, gender and age were also used as independent variables.

\section{Experience with the courts}

Whether participant had direct experience with the courts, and if yes in what role, were treated as distinct independent variables. Initially, in the first version of the questionnaire that was used to collect data from 1013 participants, participants were asked to self-identify whether they had an experience, and if yes in what role. After these data were analyzed, and answers provided were compared with follow up questions (participants were asked to provide short explanation of the experience, which was compared 
to what they stated as their experience for internal consistency), it became clear that this was not a good strategy. Some participants did not differentiate between their own experience and experience of others around them, or they would identify themselves as victims, understood as "being victimized" by the system- when in legal terms they were in fact the defendant in the case. In order to overcome these problems, the second version of the questionnaire was developed and used with the rest of the sample (2020 participants). This second version included questions about court experiences that were much more structured and free from legal jargon. These questions were structured as a decision tree, allowing it to be derived from the answers to the questions on whether or not the participant had a direct court experience, and if yes in what role. Consequently, based on the answers provided to those questions, the "court experience" variable was coded as a binary categorical variable ("has experience", and "has no experience"). Different types of court experience were treated as separate binary variables, as they are not mutually exclusive (one could have had an experience with the court as a victim, and as a defendant, at different times, for example). Six different types of experience variables were used in this analysis: 1) Defendant in criminal case, 2) victim/complainant in criminal case, 3) defendant in civil case, 4) plaintiff in civil case, 5) witness, and 6) observer/audience.

\section{Satisfaction with the court experience}

Participants who indicated that they have had an experience with the courts were asked to evaluate how satisfied they were with that experience. Those with experience as a party in a case were asked to evaluate their satisfaction with the outcome of the case, as well as to evaluate their satisfaction with their court experience in general. These two questions were asked separately, as previous research has indicated that the outcome of the trial is only one of the potential factors that influence satisfaction with the court process for parties. In fact, previous research has indicated that satisfaction with the process may have an influence on the outcome satisfaction (Casper, Tyler, \& Fisher, 1988). Those with experience as witness or an observer were asked only to evaluate their experience in general. Those evaluations were made on a 5-point Likert scale. 


\section{Trust in institutions}

All participants were asked to evaluate on a 5-point Likert scale to what degree they trust different institutions, including the government, police, municipality, press, the military, and the Constitutional Courts. Correlations between trust levels in different institutions were found to be very high (all $\mathrm{p}<$ 0.001), and therefore can be argued to be related to a general underlying trust in institutions in general. Thus, in this analysis only answers provided to "trust in government" item were used in the analysis, as a proxy for trust in institutions.

\section{RESULTS}

\subsection{Court Experience}

Using only data from the finalized questionnaire $(\mathrm{N}=2020), 29.59 \%$ of participants reported having some kind of experience with courts, and some had multiple experiences. Experience as witness and as observer were most frequent (11.7\% and $10.0 \%$. respectively). $7.4 \%$ participants reported being a plaintiff in a civil court, while $3.7 \%$ reported being a defendant in a civil court. $4.2 \%$ reported being tried as a criminal defendant in court, and $3.7 \%$ had experience with criminal courts as a victim of a crime. Since it was possible for a participant to have more than one experience with the court, the percentages adds up to more than $29.5 \%$.

Men were more likely than women to have experience with courts: $37.7 \%$ of men reported having such experience, compared to $21.6 \%$ of women. Statistics for different types of experiences indicate (as can be seen in Table 3) that men were more likely than women to have court experience in every category used in this study.

Table 3. Participants Who Reported Having Different Types of Experiences with the Courts, by Gender (\%)

\begin{tabular}{lcccccc} 
& $\begin{array}{c}\text { Criminal } \\
\text { defendant }\end{array}$ & $\begin{array}{c}\text { Criminal } \\
\text { plaintiff }\end{array}$ & $\begin{array}{c}\text { Civil } \\
\text { defendant }\end{array}$ & $\begin{array}{c}\text { Civil } \\
\text { plaintiff }\end{array}$ & Witness & Observer \\
\hline Women & 1.1 & 2.5 & 2.7 & 6.0 & 7.8 & 7.5 \\
Men & 7.3 & 4.9 & 4.7 & 8.8 & 15.6 & 12.4 \\
\hline
\end{tabular}


Table 4 shows mean age for those with and without different types of court experience. In general those with different types of court experience were on average older than those without such experience. Given that likelihood that having any kind of experience in life increases with age, this relationship was to be expected.

Table 4. Average Age of Participants by Type of Court Experience

\begin{tabular}{llllll}
\hline & \multicolumn{2}{l}{ Has experience } & \multicolumn{2}{l}{ Has no experience } & T test \\
\cline { 2 - 6 } & Mean & SD & Mean & SD & \\
\hline Any experience & 40.66 & 14.37 & 35.02 & 13.94 & $* * *$ \\
Criminal defendant & 39.83 & 12.60 & 36.55 & 14.35 & $*$ \\
Victim (criminal complaint) & 38.21 & 11.31 & 36.62 & 14.40 & \\
Civil defendant & 43.73 & 14.55 & 36.41 & 14.22 & $* * *$ \\
Civil plaintiff & 43.11 & 14.11 & 36.17 & 14.19 & $* * *$ \\
Observer & 39.41 & 15.25 & 36.39 & 14.16 & $* *$ \\
Witness & 42.12 & 13.78 & 35.97 & 14.21 & $* * *$ \\
\hline
\end{tabular}

$* \mathrm{p}<0.05 * * \mathrm{p}<0.005 * * * \mathrm{p}<0.001$

\subsection{Attitudes Towards Courts}

Since we wanted to compare participants with different types of experience in terms of their attitudes regarding courts, only data collected with finalized questionnaire were used for further analysis. Average CAI for this sample was $3.05(\mathrm{SD}=0.94)$. Mean CAI for participants who had some kind of experience with courts $(X=2.93, \mathrm{SD}=0.93)$ was significantly lower than the CAI for participants who had no experience what so ever $(X=3.14, \mathrm{SD}=0.91)[\mathrm{F}(1,1922)=20.683 ; \mathrm{p}<0.001]$. CAI means for different court experience groups are shown in Figure 1. 


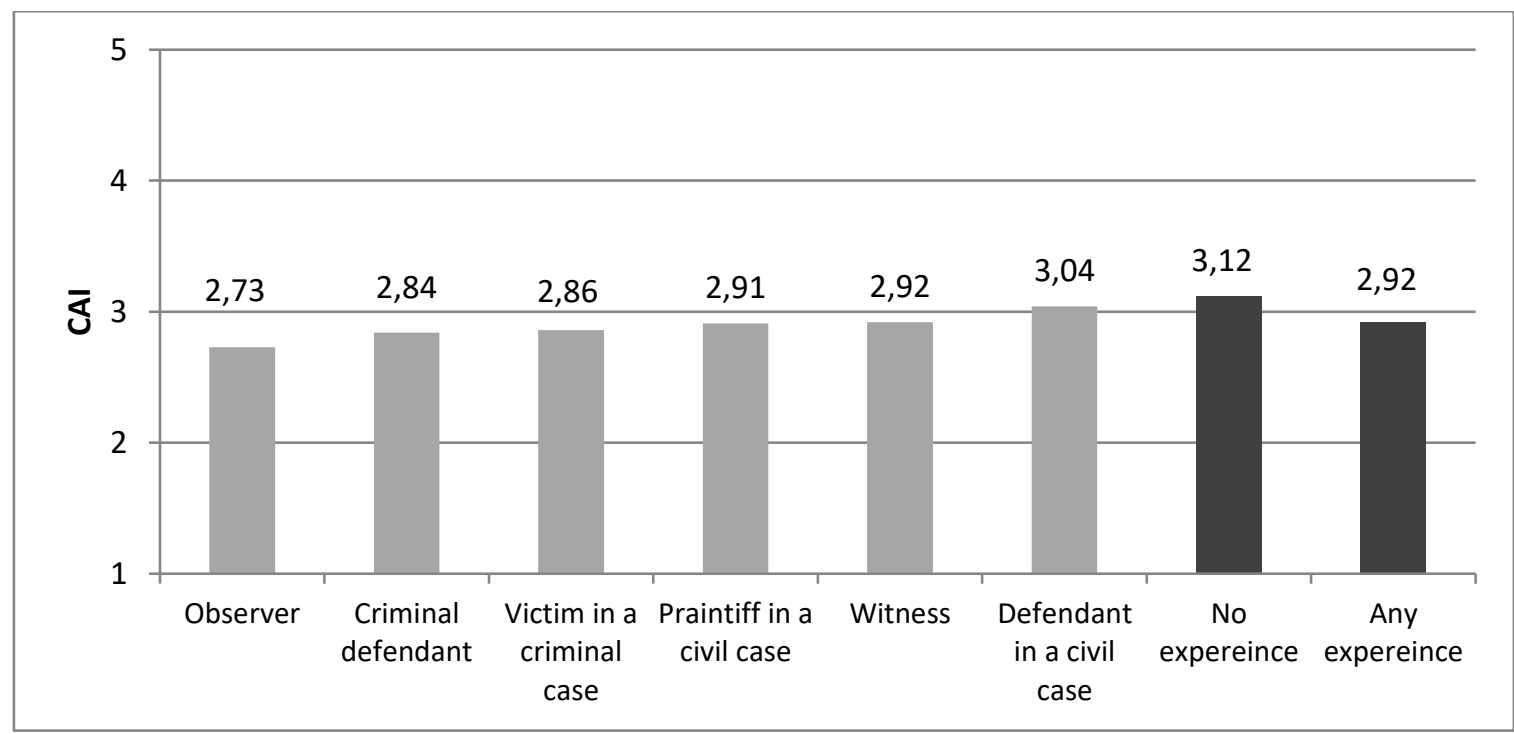

Figure 1. Court Attitude Index means for participants with different types of court experience

Regression analysis was applied to these data, using two models. In the first model "has any type of experience" was an independent variable (binary), and Court Attitude Index was the dependent variable (DV). In other words, effect of having any type of experience on one's attitudes towards the courts was analyzed. In addition to experience with the courts, age and gender were also included as IVs into the model. The model was significant $\left(\mathrm{R}^{2}=0.011, F(1,1912)=14.533, p<0.001\right)$, and age and having had an experience were found to be significant predictors of CAI (age: $\beta=0.006 ; \mathrm{t}=4.161 ; \mathrm{p}<0.001$, collinearity tolerance 0.967 ; having experience: $\beta=-2.227, \mathrm{t}=5.045, \mathrm{p}<0.001$; collinearity tolerance $0.937)$.

In order to explore whether having a particular type of experience is a better predictor than general "any type of experience" of attitudes towards the courts, a separate regression was performed using only data from participants who reported having some type of court experience ${ }^{8}$, with CAI as a DV, and the type of experience as the IV. The model was found to be significant $\left(\mathrm{R}^{2}=0.031, \mathrm{~F}(8,558)=2.246, p<0.05\right)$.

\footnotetext{
${ }^{8}$ We did not run regression analysis with "any experience" and individual types of experience as their 0 value (no experience) were $100 \%$ overlapping. While not completely mutually exclusive, 0 in any type of experience was without exception associated with 0 in all other types of experiences.
} 
However, in this model having experience with courts as an observer was the only variable that significantly predicted attitudes towards courts $(\beta=0.311, \mathrm{t}=3.744, \mathrm{p}<0.001)$.

In order to explore whether the effect of "having any experience" in the first model was solely due to the effect of having experience as an observer, regression was run again, using all participants, with age, having any type of court experience, and having experience as an observer as IVs, and CAI as DV. This model was again significant $\left(\mathrm{R}^{2}=0.027, \mathrm{~F}(3,1912)=17.782, \mathrm{p}<0.001\right)$. All three IVs were found to be significant predictors of the CAI (age $\beta=0.006, t=4.043, p<0.001$; Having any experience $\beta=-$ $0.147, \mathrm{t}=-2.884, \mathrm{p}<0.01 ;$ Having experience as an observer $\beta=-0.278, \mathrm{t}=-3.604, \mathrm{p}<0.001)$.

While the fact that models tested above were significant, it must be noted that $\mathrm{R}^{2}$ was rather low, meaning that variables in question explained limited amount of variance in the attitudes towards the courts. This can be attributed to the type of measurement used. Both "any experience" and "observer experience" variables are in fact binary categorical variables, their ability to predict precisely persons opinions regarding courts may not be very strong. In other words, while there is clear difference in the means in CAI between any- and no-experience and observer - non observer experience, knowing one person's status in terms of their court experience allows us to make only very broad, rather than precise, predictions regarding their opinions on courts.

In order to explore how general trust in institutions is associated with attitudes towards the courts, regression analysis was performed. This time age, gender, and having an experience with courts were IVs, in addition to trust in government. Dependent variable was, again, CAI. Backward stepwise regression produced a final model that was significant $\left(\mathrm{R}^{2}=0.165, \mathrm{~F}(3,1908)=125.986, \mathrm{p}<.001\right)$. Other than gender, all IVs remained in the model (Age $\beta=0.004, t=3.152, p<0.005$; Trust in government $\beta=0.232, t=18.193, p<0,001$; Having an experience with courts $\beta=-0.155, t=-3.752$, $\mathrm{p}<0,001)$. These results indicate that having an experience with courts was negatively associated with one's attitude towards courts, while age and trust in government were positively associated with those attitudes. Gender however was not found to be a significant predictor of attitudes towards courts. 
Further, to explore whether attitudes towards courts were associated with one's satisfaction with the experience of the court process and satisfaction with the outcomes of that process, additional regression analysis were performed. Separate analysis was conducted with data from only those participants who have had a particular type of experience with the court. DV in these analyses was CAI, while IVs entered into backward regression were: Age, gender, trust in government, satisfaction with the outcome of the trial process, and satisfaction with the general experience with the court. Figure 2 shows means and SDs for satisfaction with the outcome of the trial, and satisfaction with the general experience with the court process, for different categories of participants. Results of backwards regression applied to these models for different court experience groups are shown in Table 5 .

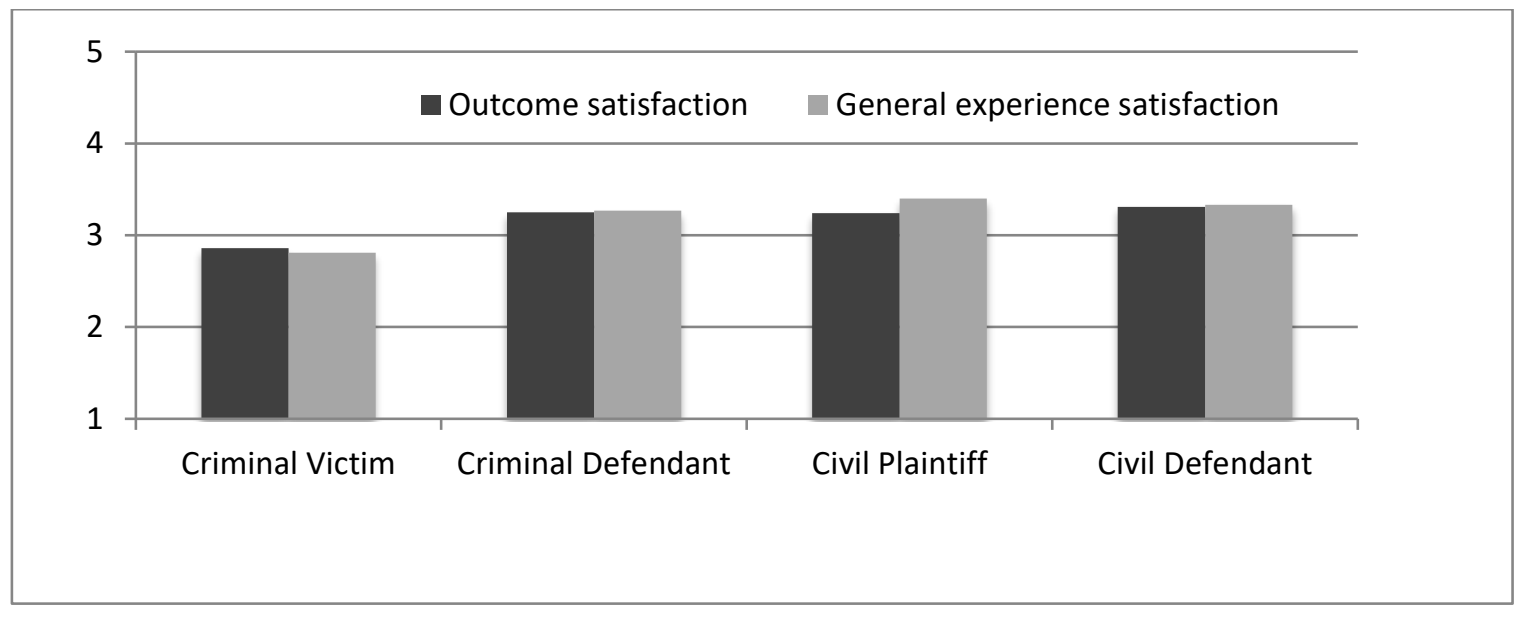

Figure 2. Trial outcome and the trial experience satisfaction, for different types of court experience.

Table 5. Backward Regression Analyses Results for Attitudes Towards Courts as DV (Final Model for Different Types of Court Experience)

\begin{tabular}{lllll}
\hline & $\mathrm{R}^{2}$ & $\mathrm{df}$ & $\mathrm{F}$ & $\mathrm{p}$ \\
\cline { 2 - 5 } Victims & 0.194 & 2,69 & 8.287 & 0.001 \\
Criminal defendants & 0.118 & 2,75 & 5.016 & 0.009 \\
Civil defendants & 0.053 & 1,67 & 3.742 & 0.057 \\
Civil plaintiffs & 0.174 & 2,134 & 14.103 & 0.000 \\
\hline
\end{tabular}


Table 6 shows variables that had remained in the final model for the participants for whom the regression model was significant (see Table 5). Trust in government remained significant predictor of attitude towards courts in the final model for all three categories of court parties. Satisfaction with the experience remained significant predictor of attitudes towards courts in the final model for victims (criminal plaintiffs) and civil plaintiffs, while satisfaction with the outcome was not a significant predictor for these two groups. Finally, for criminal defendants, outcome satisfaction was a significant predictor of attitudes towards courts, while the overall satisfaction with experience was not. Consequently, in none of the regression analyses conducted were both the outcome satisfaction and the overall experience satisfaction remain as significant predictors of the attitudes towards the courts, in the final model.

Table 6. Backward Regression Analyses Results for Attitudes Towards Courts as DV (IVs that Remained in the Final Model, for Different Types of Court Experience)

\begin{tabular}{|c|c|c|c|}
\hline \multirow[b]{2}{*}{ Indep. Variables } & \multicolumn{3}{|c|}{ Type of Court Experience } \\
\hline & Victims & $\begin{array}{l}\text { Criminal } \\
\text { defendants }\end{array}$ & $\begin{array}{l}\text { Civil } \\
\text { plaintiffs }\end{array}$ \\
\hline Age & $\mathrm{a}$ & $\mathrm{a}$ & $\mathrm{a}$ \\
\hline Gender & $\mathrm{a}$ & $\mathrm{a}$ & $\mathrm{a}$ \\
\hline Trust in government & $\begin{array}{l}\beta=0.251 \\
t=3.539 \\
p=0.001\end{array}$ & $\begin{array}{l}\beta=0.113 \\
t=2.040 \\
p=0.045\end{array}$ & $\begin{array}{l}\beta=0.209 \\
t=4.035 \\
p<0.001\end{array}$ \\
\hline $\begin{array}{ll}\text { Court } & \text { outcome } \\
\text { satisfaction } & \end{array}$ & a & $\begin{array}{l}\beta=0.145 \\
t=2.361 \\
p=0.021\end{array}$ & a \\
\hline $\begin{array}{l}\text { Court experience } \\
\text { satisfaction }\end{array}$ & $\begin{array}{l}\beta=0.146 \\
t=2.400 \\
p=0.019\end{array}$ & a & $\begin{array}{l}\beta=0.198 \\
t=3.084 \\
p=0.002\end{array}$ \\
\hline
\end{tabular}


Witnesses and observers were not asked about their satisfaction with the trial outcomes, as they were not direct parties in the cases, but were asked about their general satisfaction with the experience that they have had at the court. This, along with age, gender, and trust in government were entered as IVs into backwards regression analysis, with CAI as DV, and results are shown in Tables 7 and 8.

Table 7. Backward Regression Analyses Results for Attitudes Towards Courts as DV (Final Model for Witness and Observer Categories of Participants)

\begin{tabular}{lllll}
\hline & $\mathrm{R}^{2}$ & $\mathrm{df}$ & $\mathrm{F}$ & $\mathrm{p}$ \\
\cline { 2 - 5 } Witness & 0.406 & 2,215 & 21.224 & $<0.001$ \\
Observer & 0.532 & 2,189 & 37.342 & $<0.001$ \\
\hline
\end{tabular}

Table 8. Backward Regression Analyses Results for Attitudes Towards Courts as DV (IVs that Remained in the Final Model, for Witness and Observer Categories of Participants)

\begin{tabular}{l|ll}
\hline Indep. Variables & Witnesses & Observer \\
\hline Age & a & a \\
& & \\
\hline Gender & a & \\
& & \\
\hline & $\beta=0.202$ & $\beta=0.271$ \\
Trust in government & $\mathrm{t}=5.186$ & $\mathrm{t}=6.836$ \\
& $\mathrm{p}<0.000$ & $\mathrm{p}<0.001$ \\
& & \\
\hline \multirow{3}{*}{ Trial experience satisfaction } & $\beta=0.169$ & $\beta=0.231$ \\
& $\mathrm{t}=3.305$ & $\mathrm{t}=4.142$ \\
- & $\mathrm{p}=0.001$ & $\mathrm{p}<0.000$
\end{tabular}

${ }^{\mathrm{a}}$ Variable did not remain in the final model

Once again trust in government was a significant predictor of attitudes towards courts, as was general satisfaction with the court experience. Age and gender lost their predictive power in the multivariate analysis. 


\section{DISCUSSION}

To summarize, the goal of this secondary analysis was to test whether and how citizens' first-hand experiences with the courts influence their attitudes regarding the courts. In particular we explored how the satisfaction with the outcome and with the process that citizens witness/are subject to, shape their attitudes.

It was found that $70.5 \%$ of participants did not have any direct experience with courts, and women were somewhat less likely to have a court experience then men ( $78.4 \%$ women reported no experience, versus $62.3 \%$ men). This is in line with other findings from Turkey, that indicated that women used civil courts for family matters only (such as divorce, alimony, etc.), and rarely pursued any economic claims in courts (Elveriş, Jahic, \& Kalem, 2009). Further, justice statistics indicate that an overwhelming majority of all prosecuted for criminal offences are men, leaving women almost completely out of that category (Ministry of Justice, 2018). It appears that the relative underrepresentation of women in public, social and economic life is also reflected in their underrepresentation in the courts.

In general, the attitudes towards the courts were found to be close to the mid-point, and followed a normal distribution patterns. We found a relatively small, but statistically significant difference between attitudes towards courts of those who had and those who did not have a direct experience with the courts, with those with the experience having slightly more negative attitudes. When trying to look whether results differentiated by type of experience, it was found that being an observer was by itself a significant predictor, while having other types of experience, individually, was not. In other words, observing court in work without being a party was separately associated with attitudes towards courts, while all other types of experiences did not individually associate with the attitudes towards courts.

It should be noted that only about $3 \%$ of variance in the attitudes towards courts can be predicted by simply knowing whether a person had a direct experience with courts. While statistically significant, this finding is clearly not groundbreaking. However, the fact that participating in a court process was associated with more negative attitudes towards courts is a finding that needs more consideration, as it 
supports the argument that direct experience with courts in fact breeds overall contempt, rather than respect, towards the courts.

Our analysis further indicated that, for some types of court experiences, satisfaction with the court process was associated with attitudes towards courts, while this was not the case for satisfaction with the outcomes. In other words, outcome of the court process, and one's satisfaction with it, was not the main factor influencing the attitudes towards the courts for some of the participants (victims in the criminal process and civil plaintiffs). For the same participants, however, the degree of satisfaction with the court experience was associated with their attitudes. In this study, this was the case with victims in criminal process and civil plaintiffs. For offenders (criminal defendants) the reverse was true: Outcome satisfaction was associated with attitudes while the satisfaction with the general experience with the courts was not. Based on these findings, it can be concluded that satisfaction with the outcome, and satisfaction with the court experience in general, have varying effects on the attitudes towards the courts. For none of the groups, both predicted the attitudes towards the courts, indicating that these two variables (satisfaction with outcome and satisfaction with the court experience) are independent of one another.

These findings suggest that for parties that "make demands" from the legal process (victims and plaintiffs who put the legal system in motion) the outcome is less important compared to those who are in the position of defense (criminal defendants). The fact that for people who are in front of the court with the claim of being harmed (i.e. victims and civil plaintiffs), the overall experience is actually more important than the outcome of the case suggests that these groups of participants have fundamentally different sets of expectations from courts and the judicial system from defendants in criminal cases, who are accused by the system. While the former wants to see a positive overall experience, the latter group prefers to see a favorable outcome, and they base their assessment of their experiences using these different frameworks. The fact that for witnesses and observers satisfaction with the experience was also positively associated with attitudes towards courts strengthens the argument put forward by the procedural justice theory that satisfaction with the process itself has an important and a distinct effect on how one evaluates the courts, that subjective experiences matter when making such evaluations, and 
that outcomes of the judicial process are not the most important parts of the court experience, except for criminal defendants.

When it comes to other variables, it was found that trust in government was positively associated with attitudes towards courts, for all categories, while age and gender were not. High correlation between trust in government and attitudes towards the courts indicates that this reflects a stable underlying attitude of "trust in institutions" in general, and courts included. This brings up the question of differentiation between the concepts: If trust in courts is strongly influenced by an underlying and overreaching trust in institutions, can actual experience with the court (and if yes, by how much) change and shape the attitudes towards the courts?

Our research findings indicate that attitudes towards courts do have what one could call a "stable component" - a base attitude that is rooted in one's general attitude towards institutions in a more abstract sense. This base attitude however is combined with a "flexible component" which is experience based, and it reflects the effect of the satisfaction with the court outcomes and the court experience. While the base component, measured in this research as "trust in government", was a stronger predictor of the attitudes towards courts in almost all analyses performed, the difference in the relative strengths of the predictive powers of the base and the flexible component was not drastic in any of the models. This leads us to conclude that attitudes towards courts are not solely an unshakable expression of one's general trust in institutions, and in fact can be altered as a result of having an experience with the courts. Based on our findings, a positive assessment of the process will improve those attitudes for most roles in courts, while outcomes will only have that effect for criminal defendants.

One major drawback of this study is that did not involve any pre-post measures, so it is difficult to support the cause-effect interpretation of the uncovered associations. However, when it comes to the relationship between court experiences and attitudes, this is less of an issue, as the decision whether to be a party in a case or not is not just a matter of free choice. In fact, one often does not have any choice, as in the case of defendants, and sometimes also victims in criminal cases (as prosecutor can decide to 
prosecute, regardless of whether that is also desired by the victim). Even in cases where a person has a choice whether to take a dispute to the court or not, that choice is also complicated by the fact that people usually go to courts as a last resort, when they feel like they do not have any other choice. In other words, in most cases, being in a court is not something that you do, but rather something that happens to you. If, in fact, positive attitudes towards courts were the driving influence behind seeking a solution to legal problems in courts, one would expect to see a positive relationship between participation in the court process and attitudes towards courts. In this study, the opposite was found. It is difficult to envision a scenario in which negative attitudes towards courts would drive one to initiate a court process. Hence, it is reasonable to conclude that negative attitudes of those who had experience with courts are in fact the result of the quality of the experience that they have had with the courts, rather than the other way around.

Our findings have strong policy implication. Assuming that positive attitudes towards courts among the public is a desirable policy outcome for any government, especially due to the link between such attitudes and perceived legitimacy of the courts, our results present a roadmap with two paths towards shaping those attitudes. Following the more general path, attitudes towards courts can be improved as a result of general increase in trust towards the government. While this is not an easy task, a policy that aims to improve the trust in government would arguably also lead to improved attitudes towards courts, without specifically addressing the court process. Alternatively, and perhaps much more plausibly, improving the experience of the court process could also produce similar results. This could be achieved by developing practices that have been proven to improve people's experiences with the court process. In particular, practices based on procedural and restorative justice, both of which attach significance to how people interact with the courts and the court process, and place public's experience at the center of the justice process, should be used to draw the framework for such policy initiatives. However, as this research suggests, some citizens may not be influenced by such policies, criminal defendants in particular, who have been found to value desirable outcomes more. While policy cannot be structured so as to result in particular outcomes in specific cases, the varieties of possible outcomes for criminal 
defendants can in fact be increased through policy, creating alternatives to punishment, for different categories of offenders. Existence of such diversion mechanisms ${ }^{9}$ could arguably result in improvement in satisfaction with the outcomes, as "loosing" for the offender may not necessarily lead to prison or fines, but to a whole range of alternatives which may be seen as more just or at least acceptable by the offenders.

\footnotetext{
${ }^{9}$ Diversion in criminal justice literature refers to programs that "seek to avoid formal processing of an offender by the criminal justice system" and typically results in treatment or other case programs instead of prosecution of the offender (Dammer \& Erise-Pengelly, 2016).
} 


\section{ÖZET}

$\mathrm{Bu}$ çalışmada, Türkiye'de mahkemelerde farklı rollerde bulunmuş kişilerin bu deneyimlerinin mahkemelere yönelik tutumları üzerindeki etkisi incelenmiştir. Çalışma, 2006-2007 yılları arasında Türkiye genelinde yetişkin nüfus arasında gerçekleştirilen ve kişilerin genel olarak hukukun ve yargının işleyişine dair bilgilerini ölçmeye ve bu alandaki deneyimlerini anlamaya yönelik saha araştırmasının verilerinin ikincil analizini içermektedir. Bu çerçevede çalışma, Türkiye'de kullanıcıların mahkeme deneyimlerinden memnun olup olmadıklarından veya bu deneyimi nelerin şekillendirdiğinden ziyade, ilişkisel bir analize odaklanır ve mahkemeler ile doğrudan deneyimin ve bu deneyimden memnuniyetin, tutumları etkileyip etkilemediğini sorgulamaktadır.

Sonuçlar, mahkeme deneyimi olan kişilerin tutumlarının, hiç mahkeme deneyimi olmayan kişilere göre daha olumsuz olduğunu göstermiştir. Kişiler mahkeme de izleyici olarak da taraf olarak da yer alsalar her durumda mahkeme deneyimi tutumları olumsuz etkilemektedir. Bu sonuç, yargılamadaki rollerden bağımsız olarak doğrudan deneyimin olumsuz etki bıraktığını ortaya koymaktadır. Öte yandan, çalışmada aynı zamanda süreçten ve sonuçtan memnuniyetin de tutumlar üzerindeki etkisi ayrıca incelenmiştir ve buradaki bulgular roller arasında farklılara işaret etmektedir. Nitekim ceza davalarında mağdur ve hukuk davalarında davacı olanlar ile mahkemelerde izleyici ya da tanık rolünde deneyimleri olanlar için deneyimden memnuniyet mahkemelere yönelik tutumları olumlu yönde etkilerken, sanıklar söz konusu olduğunda sonuçtan memnuniyetin aynı etkiyi yarattı̆ğ görülmektedir. Aynı zamanda hükümete güvenin de tüm gruplar için mahkemelere yönelik tutumları belirleyici bir etkisi olduğu görülmüştür. Sonuç olarak, mahkemelere yönelik tutumların iki unsur üzerinden belirlendiği öne sürülür: katı olan bir temel bileşen ve esnek ve deneyime dayalı bir bileşen. Katı temel bileşen, hükümete ve kurumlara yönelik daha genel ve soyut bir tutumun ve güvenin bir yansıması iken, esnek bileşen ise deneyimin özellikleriyle ve de kişilerin gerçekte mahkemelerde karşılaştıkları üzerinden şekillenmektedir.

Çalışmanın bu sonuçlarla, yargı alanında geliştirilecek politikalara özellikle katkı sağlayacağına inanılmaktadır. Özellikle de süreç deneyiminin tutumları etkilemedeki gücüne odaklanıldığında, sürece 
ilişkin yapılacak iyileştirmelerin doğrudan tutumları etkileyebileceği öne sürülmektedir. Nitekim gerek süreç adaleti gerekse onarıcı adalet alanındaki çalışmalarda da bireylerin adalet algılarının ve deneyimlerinin iyileştirilmesinin hukuk sisteminin meşruiyetine olan etkisinin yanı sıra, bu iyileştirmelerin doğrudan adalete erişim alanındaki politikalara olan katkıları da tartışılmaktadır. Öte yandan, sürece yönelik iyileştirmelerin her grubun tutumunu etkilemeyeceği de ayrıca görülmüştür. Nitekim sanıklar her koşulda sonuçtan memnun olmayı daha fazla önemsemektedirler. Esasa ilişkin değişiklik yapılmasını öngörmek yargı bağımsızlı̆̆ ilkesiyle bağdaşmayacaktır kuşkusuz, ancak sonuçtan memnuniyet farklı suç kategorileri için ceza alternatifleri geliştirilerek de sağlanabilir. Bu alternatifler hapis/para cezası almak veya almamak üzerinden tanımlanan sonuçları çeşitlendirerek, sanıklar için de daha olumlu bir deneyimi mümkün kılabilir. 


\section{REFERENCES}

Benesh, S. C. (2006). Understanding Public Confidence in American Courts. The Journal of Politics, 68(3), 697-707. Doi: 10.1111/j.1468-2508.2006.00455.

Benesh, S. C., Howell, S. E. (2001). Confidence in the Courts: A Comparison of Users and NonUsers. Behavioral Sciences \& The Law, 19(2), 199-214. Doi: 10.1002/bsl.437.

Bohner G, Schwarz N. (2001). Attitudes, Persuasion, and Behavior. In A. Tesser \& N. Schwarz (Eds.), Blackwell Handbook of Social Psychology, Vol. 1: Intraindividual Processes (413-435). Oxford, UK: Blackwell.

Bourdieu, P. (1987). The Force of Laq: Toward a Sociology of the Juridical Field, Hastings Law Journal, 38/5, 814-853.

Breckler, S. J. (1984). Empirical Validation of Affect,Behavior, and Cognition as Distinct Components of Attitude. Journal of Personality and Social Psychology, 47, 1191-1205. Doi: 10.1037/00223514.47.6.1191.

Brunson, R. K. (2007). Police Don't Like Black People: African-American Young Men's Accumulated Police Experiences. Criminology \& Public Policy, 8 (1), 71-101. Doi: 10.1111/j.17459133.2007.00423.

Bühlmann, M., \& Kunz, R. (2011) Confidence in the Judiciary: Comparing the Independence and Legitimacy of Judicial Systems. West European Politics, 34(2), 317-345. Doi: 10.1080/01402382.2011.546576.

Casper, J. D. (1978). Having Their Day in Court: Defendant Evaluations of the Fairness of Their Treatment. Law \& Society Review, 12(2), 237-251. Retrieved from https://www.jstor.org/stable/3053234.

Casper, J. D., Tyler, T., \& Fisher, B. (1988). Procedural Justice in Felony Cases. Law \& Society Review, 22(3), 483-507. Retrieved from https://www.jstor.org/stable/3053626?seq=1.

Chapman, B., Mirrlees-Black, C., \& Brawn, C. (2002). Improving Public Attitudes to the Criminal Justice System: The Impact of Information. Home Office: London. Retrieved from https://www.prisonlegalnews.org/media/publications/home office research study 245 impro ving public attitudes on the criminal justice system 2002.pdf.

Dammer, H. R., \& Erise_Pengelly, V. A. (2016). Diversion. In Encyclopaedia Britannica. Retrieved from https://bit.ly/2E7rhL3. 
Elveriş, I., Jahic, G., \& Kalem, S. (2009). Judicial Proceedings at Istanbul Civil Courts: Parties, Cases and Process. Istanbul, Turkey: İstanbul Bilgi Ünivesitesi Yayınları.

Ewick, P., Silbey, S. S. (1998). The Common Place of Law: Stories from Everyday Life. University of Chicago Press.

Fix-Fierro, H. (2003). Courts, Justice and Efficiency: A Socio-Legal Study of Economic Rationality in Adjudication. Hart Publishing.

Gibson, J. L. (2018). Black and Blue: How African Americans Judge the U.S. Legal System. USA: Oxford University Press.

Grootelaar, H. A. M. (2018). Interacting with Procedural Justice in Courts (Unpublished doctoral dissertation). Utrecht, Netherlands: Utrecht University.

Grootelaar, H. A.M, \& van den Bos, K. (2018). How Litigants in Dutch Courtrooms Come to Trust Judges: The Role of Perceived Procedural Justice, Outcome Favorability, and Other Sociolegal Moderators. Law \& Society Review, 52(1), 234-268. Doi: 10.1111/lasr.12315.

Hazzard, A. (1983). Children's Experience with, Knowledge of, and Attitude toward Disabled Persons. The Journal of Special Education, 17(2), 131-139. Doi: $10.1177 / 002246698301700204$.

Higgins, G. E., Jordan, K. L. (2005). Race and Gender: An Examination of the Models that Explain Evaluations of the Court System for Differences. Criminal Justice Studies, 18(1), 81-97. Doi: $10.1080 / 14786010500071188$.

Hough, M., Jackson, J., Bradford, B., Myhill, A., \& Quinton, P. (2010). Procedural Justice, Trust, and Institutional Legitimacy. Policing: A Journal of Policy and Practice, 4(3), 203-210. Doi: 10.1093/police/paq027

Hough, M., Bradford, B., Jackson, J., \& Roberts, J. V. (2013). Attitudes to Sentencing and Trust in Justice: Exploring Trends from the Crime Survey for England and Wales. Ministry of Justice Analytical Series. London, UK: Ministry of Justice. Retrieved from http://eprints.bbk.ac.uk/5195/.

Hulst, L., Van den Bos, K., Akkermans, A. J., \& Lind, E. A. (2017). On Why Procedural Justice Matters in Court Hearings. Utrecht Law Review, 13 (3), 114-129. Doi: 10.18352/ulr.413. 
Jacquot, S., Vitale, T. (2014). Law as Weapon of the Weak? A Comparative Analysis of Legal Mobilization by Roma and Women's Groups at the European Level. Journal of European Public Policy, 21(4), 587-604. Doi: 10.1080/13501763.2014.887138.

Jahic, G. \& Kalem, S. (2009). Vatandaşın Gözünden Mahkemeler: Katilim, Tutumlar ve Güven. In S. Kalem (Ed.), Adalet Gözet: Yargi Sistemi Üzerine Bir Inceleme (27-70). İstanbul, Turkey: İstanbul Bilgi Üniversitesi Yayınları.

Jay, G. M., \& Willis, S. L. (1992). Influence of Direct Computer Experience on Older Adults' Attitudes toward Computers. Journal of Gerontology, 47(4), 250-257. Doi: 10.1093/geronj/47.4.P250.

Kalem, S. (Ed.). (2009). Adalet Gözet: Yargı Sistemi Üzerine Bir Inceleme. İstanbul, Turkey: İstanbul Bilgi Üniversitesi Yayınları.

Kalem, S., Jahic, G. \& Elveriş, İ. (2008). Justice Barometer: Public Opinions on Courts in Turkey. Istanbul, Turkey: İstanbul Bilgi University Publications.

Kritzer, H. M. \& Voelker, J. (1998). Familiarity Breeds Respect: How Wisconsin Citizens View Their $\begin{array}{lllll}\text { Courts. } & \text { Judicature, } & \text { 82(2), } & \text { 58-64. } & \text { Retrieved }\end{array}$ https://heinonline.org/HOL/LandingPage?handle=hein.journals/judica82\&div=21\&id=\&page.

Lind, E. A., Tyler, T. R. (1988). The Social Psychology of Procedural Justice. Springer Science \& Business Media.

Lind, E. A., Kulik, C. T., Ambrose, M., \& de Vera Park, M. V. (1993). Individual and corporate Dispute Resolution: Using Procedural Fairness As A Decision Heuristic. Administrative Science Quarterly, 38(2), 224-251. Doi: 10.2307/2393412.

Luhmann, N. (2004). Law As A Social System. Oxford, UK: Oxford University Press,

Macaulay, S. (1987). Images of Law in Everyday Life: The Lessons of School, Entertainment, and Spectator Sports. Law \& Society Review, 21(2), 185-218. Doi: 10.2307/3053519.

Mazer, D. B., Percival, E. F. (1989). Ideology or Experience? The Relationships Among Perceptions, Attitudes, and Experiences of Sexual Harassment in University Students. Sex Roles, 20(3-4), 135-147. Doi: 10.1007/BF00287987.

McCoy, C., Jahic, G. (2006). Familiarity Breeds Respect: Organizing and Studying A Courtwatch. Justice System Journal, 27(1), 61-70. Doi: 10.1080/0098261X.2006.10767787. 
Merry, S. E. (1990). Getting Justice, Getting Even: Legal Consciousness Among Working-Class Americans. Chicago, IL: The University of Chicago Press.

Ministry of Justice (2018). Justice Statistics 2017. Ankara: T.C. Adalet Bakanlığı, Adli Sicil ve İstatistik Genel Müdürlüğü.

Mondak, J.J., Hurwitz, J., Peffley, M., and Testa, P. (2017). The Vicarious Bases of Perceived Injustice. American Journal of Political Science, 61(4), 804-819. Doi: 10.1111/ajps.12297.

Moorhead, R., Sefton, M., \& Scanlan, L. (2007). Just Satisfaction? What Drives Public and Participant Satisfaction with Courts and Tribunals-A Review of Recent Evidence. What Drives Public and Participant Satisfaction with Courts and Tribunals-A Review of Recent Evidence. [Technical Report]. Crown. Ministry of Justice Research Series 5/08. Doi: 10.2139/ssrn.2425127.

O'Barr, W. M., Conley, J. M. (1988). Lay Expectations of the Civil Justice System. Law \& Society Review, 22, 137. Retrieved from https://heinonline.org/HOL/LandingPage?handle=hein.journals/lwsocrw22\&div=10\&id=\&pag $\underline{\mathrm{e}=}$

Olson, J. M., Zanna, M. P. (1993). Attitudes and Attitude Change. Annual Review of Psychology, 44(1), 117-154. Doi: 10.1146/annurev.ps.44.020193.001001.

Pleasence, P., Balmer, N. (2018). Measuring the Accessibility and Equality of Civil Justice. Hague Journal on the Rule of Law, 10(2), 255-294. Doi: 10.1007/s40803-018-0079-0.

Quinton, P. (2011). The Impact of Information about Crime and Policing on Public Perceptions: The Results of A Randomised Controlled Trial. London: National Policing Improvement Agency.

Rosenberg, M. J., Hovland, C. 1. (1960). Cognitive, Affective, and Behavioral Components of Attitude. In M. J. Rosenberg, C. I. Hovland, W. J. McGuire, R. P. Abelson, \& J. W. Brehm (Eds.), Attitude Organization and Change. An Analysis of Consistency Among Attitude Components (1-14). New Haven, CT: Yale University Press.

Rottman, D. B., Hansen, R., Mott, N., \& Grimes, L. (2003). Perceptions of the Courts in Your Community: The Influence of Experience, Race, and Ethnicity. Williamsburg, VA: National Center for State Courts. Retrieved from https://www.ncjrs.gov/pdffiles1/nij/grants/201302.pdf.

Schwarz, N., Bohner, G. (2001). The Construction of Attitudes. In: A. Tesser, \& N. Schwarz (Eds.), Blackwell Handbook of Social Psychology, Vol. 1: Intraindividual Processes (436-457). Oxford, UK: Blackwell. 
Silbey, S. S. (2005). After Legal Consciousness. Annual Review of Law and Social Science, 1, 323-368. Doi: 10.1146/annurev.lawsocsci.1.041604.115938.

Silbey, S. S., Cavicchi, A. (2005). The Common Place of Law: Transforming Matters of Concern into the Objects of Everyday Life. In B. Latour, \& P. Weibel (Eds.), Making Things Public: Atmospheres of Democracy. ZKM Center for Art and Media Karlsruhe. Cambridge, Massachussetts: The MIT Press.

Sun, I. Y., \& Wu, Y. (2006). Citizens' Perceptions of the Courts: The Impact of Race, Gender, and Recent Experience. Journal of Criminal Justice, 34(5), 457-467. Doi: 10.1016/j.jcrimjus.2006.09.001.

Thibaut, J. W., \& Walker, L. (1975). Procedural Justice: A Psychological Analysis. Hilllsdale, NJ: Lawrence Erlbaum Associates.

Tunç, A. (2009). Türkiye'de Yazılı Basının Yargıya İlişkin Haberleri Sunumu. In S. Kalem (Ed.), Adalet Gözet: YargI Sistemi Üzerine Bir İnceleme (117-147). Istanbul, Turkey: İstanbul Bilgi Üniversitesi Yayınları.

Turk, A. T. (1976). Law As A Weapon in Social Conflict. Social Problems, 23(3), 276-291. Doi: $10.2307 / 799774$.

TÜiK (n.d.) Nüfus Projeksiyonlar1: Y1l Ortas1 Nüfus. Retrieved 4 December 2019, from http://2018.www.tuik.gov.tr/PreTablo.do?alt_id=1027.

Tyler, T. R. (1990). Justice, Self-Interest, and The Legitimacy of Legal and Political Authority. In J. J. Mansbridge (Ed.), Beyond Self-Interest (171-179). Chicago, IL: University of Chicago Press.

Tyler, T. R. (2001). Public Trust and Confidence in Legal Authorities: What Do Majority and Minority Group Members Want from the Law and Legal Institutions?. Behavioral Sciences \& The Law, 19(2), 215-235. Doi: 10.1002/bsl.438.

Tyler, T. R. (2006). Why People Obey the Law. Princeton, NJ: Princeton University Press.

Tyler, T. R., Huo, Y. J. (2002). Trust in the Law: Encouraging Public Cooperation with the Police and Courts. New York, NY: Russell Sage Foundation.

Weber, M. (1958). The Three Types of Legitimate Rule. H. Gerth (Trans.). Berkeley Publications in Society and Institutions, 4(1), 1-11. 
Wilson, C. (2012). The Public and The Justice System: Attitudes, Drivers and Behavior - A Literature Scottish

Government.

Retrieved

from https://www2.gov.scot/resource/0039/00396342.pdf. 